\title{
Is insulin-like growth factor-1 involved in Parkinson's disease development?
}

\author{
Inma Castilla-Cortázar ${ }^{1,2^{*}}$, Gabriel A. Aguirre ${ }^{3}$, Giovana Femat-Roldán ${ }^{1,4}$, Irene Martín-Estal ${ }^{1}$ and Luis Espinosa ${ }^{1}$
}

\begin{abstract}
Parkinson's disease (PD) is a neurodegenerative disorder that results in the death of dopaminergic neurons within the substantia nigra pars compacta and the reduction in dopaminergic control over striatal output neurons, leading to a movement disorder most commonly characterized by akinesia or bradykinesia, rigidity and tremor. Also, PD is less frequently depicted by sensory symptoms (pain and tingling), hyposmia, sleep alterations, depression and anxiety, and abnormal executive and working memory related functions. On the other hand, insulin-like growth factor 1 (IGF-1) is an endocrine, paracrine and autocrine hormone with several functions including tissue growth and development, insulin-like activity, proliferation, pro-survival, anti-aging, antioxidant and neuroprotection, among others. Herein this review tries to summarize all experimental and clinical data to understand the pathophysiology and development of PD, as well as its clear association with IGF-1, supported by several lines of evidence: (1) IGF-1 decreases with age, while aging is the major risk for PD establishment and development; (2) numerous basic and translational data have appointed direct protective and homeostasis IGF-1 roles in all brain cells; (3) estrogens seem to confer women strong protection to PD via IGF-1; and (4) clinical correlations in PD cohorts have confirmed elevated IGF-1 levels at the onset of the disease, suggesting an ongoing compensatory or "fight-to-injury" mechanism.
\end{abstract}

Keywords: Parkinson's disease, IGF-1, Aging, Dopamine, Estrogens, Central nervous system

\section{Background: aspects and clinical features of Parkinson's disease}

Parkinson's disease (PD) was first medically described as a neurological syndrome by James Parkinson in 1817. Over 50 years later, Jean Martin Charcot was more exhaustive in his descriptions and distinguished bradykinesia as a separate cardinal feature of this illness [1].

$\mathrm{PD}$ is the second most common neurodegenerative disorder, being age one of the main risk factors for its development $[2,3]$. Despite years of study, much is still unknown about its etiology and pathogenesis, although genetic and environmental factors are involved in the establishment of the disease. However, the identification of such factors, their interaction and the associated

\footnotetext{
*Correspondence: iccortazar@gmail.com; iccortazar@hmhospitales.com

${ }^{2}$ Fundación de Investigación HM Hospitales, Madrid, Spain

Full list of author information is available at the end of the article
}

molecular pathways that lead to neurodegeneration are weakly comprehended.

There are multiple motor and non-motor symptoms that can develop in the course of PD (Fig. 1). This disorder is characterized by the appearance of progressive motor deficit, having four cardinal symptoms grouped in the acronym "TRAP": tremor at rest, rigidity, bradykinesia and postural instability. To these, postural changes in flexion (camptocormia) and freezing are added as the most characteristic signs of the disease, impeding daily patient's daily life activities $[4,5]$.

Tremor is the most common symptom of PD characterized by being at rest with unilateral and distal initiation at a frequency of $4-6 \mathrm{~Hz}$, with a movement in prone-supine position like "counting coins". This sign may occur in arms, legs, lips and jaw [5-8]. The rigidity observed in PD is described as an increase in muscle tone manifested by a resistance to passive movement. It is usually accompanied by a phenomenon called cogwheel

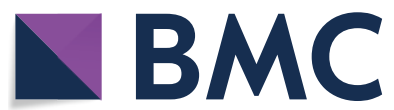

(c) The Author(s) 2020. This article is licensed under a Creative Commons Attribution 4.0 International License, which permits use, sharing, adaptation, distribution and reproduction in any medium or format, as long as you give appropriate credit to the original author(s) and the source, provide a link to the Creative Commons licence, and indicate if changes were made. The images or other third party material in this article are included in the article's Creative Commons licence, unless indicated otherwise in a credit line to the material. If material is not included in the article's Creative Commons licence and your intended use is not permitted by statutory regulation or exceeds the permitted use, you will need to obtain permission directly from the copyright holder. To view a copy of this licence, visit http://creativeco mmons.org/licenses/by/4.0/. The Creative Commons Public Domain Dedication waiver (http://creativecommons.org/publicdomain/ zero/1.0/) applies to the data made available in this article, unless otherwise stated in a credit line to the data. 


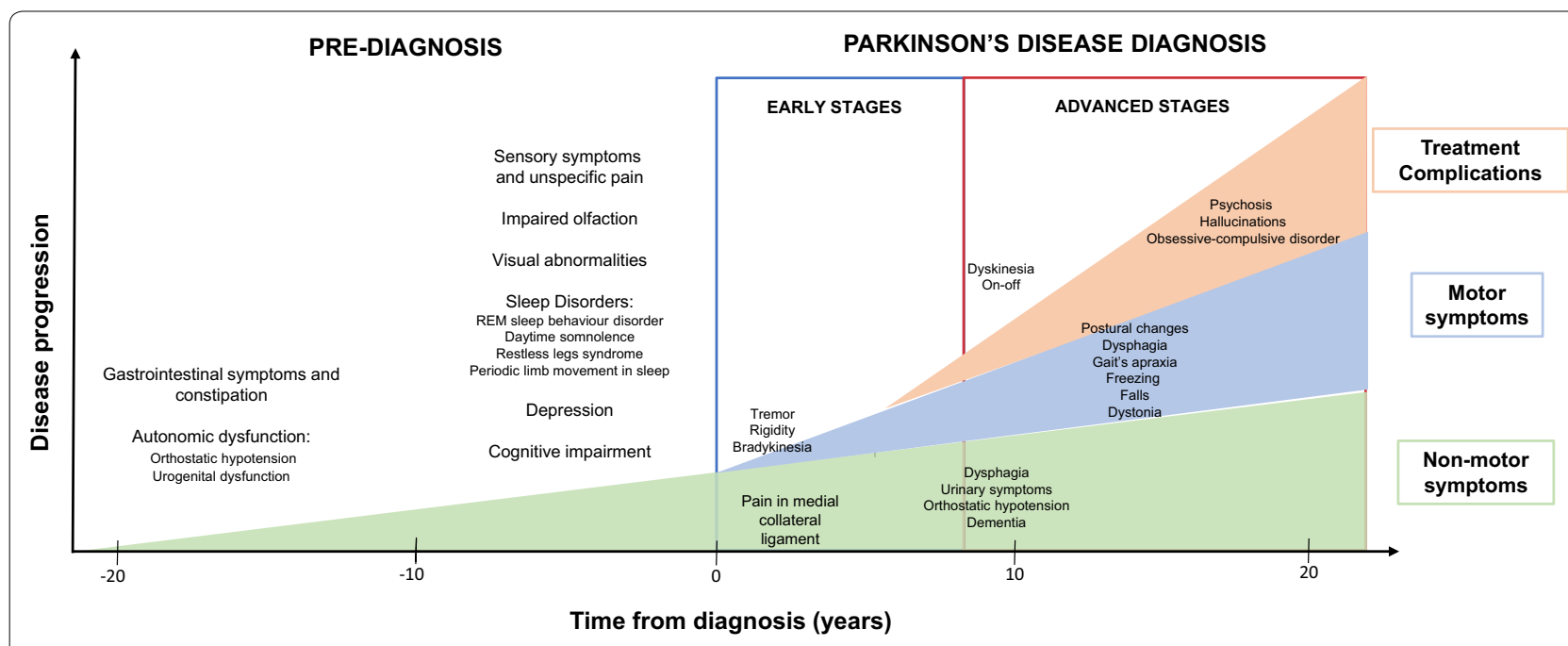

Fig. 1 Chronology of clinical symptoms in Parkinson's disease (modified from Kalia et al. [8]). Schematic representation of the diagnosis (even 10 to 20 years before the onset of the disease) and motor/non-motor symptoms in early and advanced stages of Parkinson's disease, with clinical and other iatrogenic symptoms

[9]. Bradykinesia is depicted by difficulty in movement planning, initiation and execution [10]. Other manifestations associated with bradykinesia are the loss of spontaneous movements, hypomimia, hypophonia and deficit in arm-accompanying movement when walking $[10,11]$. Postural instability appears late in the course of PD and is described as the loss of postural reflexes. These last alterations are frequent in PD patients, mainly camptocormia, which is characterized by neck, trunk, elbows and knees flexion. Nonetheless, other postural changes may occur, e.g. Pisa syndrome [10].

The freezing phenomenon is described as an inability to achieve movements, typically occurred during walking, producing severe disability. It usually lasts less than $10 \mathrm{~s}$, but it can be prolonged. Freezing is accompanied by a festive march and it can be aggravated when turning around during the march or in closed spaces [9].

\section{Physiopathology of Parkinson's disease}

The function of basal ganglia is determined by the balance between direct and indirect pathways activated by gamma-aminobutyric acid (GABA) neurotransmitter. The direct pathway starts with the activation of D1 dopamine receptors by dopamine in the striatum, which inhibit (via GABA) the globus pallidus pars interna. This last brain structure, in the absence of dopamine would inhibit the thalamus. Consequently, the direct pathway hinders the inhibition of the thalamus, thus stimulating the cortex (Fig. 2) [12]. On the other hand, the indirect pathway starts with the activation of dopamine D2 receptors in the striatum, inhibiting the globus pallidus pars externa, which in turn would inhibit (via GABA) the subthalamic nucleus. Due to the lack of inhibition by globus pallidus, the subthalamic nucleus activates the globus pallidus pars interna, which hinders (via GABA) the thalamus, hence inhibiting the cortex (Fig. 2) [12]. As follows, the direct pathway results in an excitation of the cortex, as opposed to the indirect pathway, where an inhibition of the cortex occurs.

The balance between these two pathways, regulated by dopaminergic afferent neurons in the substantia nigra pars compacta ascending to the basal ganglia, is progressively affected in PD. Thus, gradual loss of dopaminergic projections hinder the direct pathway, stimulating the globus pallidus pars interna that inhibit (via GABA) the thalamus leading to cortical dysfunction (Fig. 2) [12].

Motor activation alterations in PD patients reflect basal ganglia projection dysfunctions towards motor cortex as a result of the nigrostriatal degeneration, typified by progressive cell death in the central nervous system (CNS). The abnormal neuronal activity in areas receiving excessive inhibition of thalamo-cortical projections in PD has been evident in neuroimaging studies where they are hypoactive, such as the primary motor area (M1), supplementary motor area (AMA) and the lateral prefrontal cortex (DLPFC) [12].

Nonetheless, PD pathophysiology is not fully understood. It can be assumed that PD establishment depends upon various mechanisms, such as dopamine depletion, direct and indirect pathways alterations of the basal ganglia, dysfunction of the basal ganglia to the cortex and abnormal cortical plasticity [12]. PD motor 


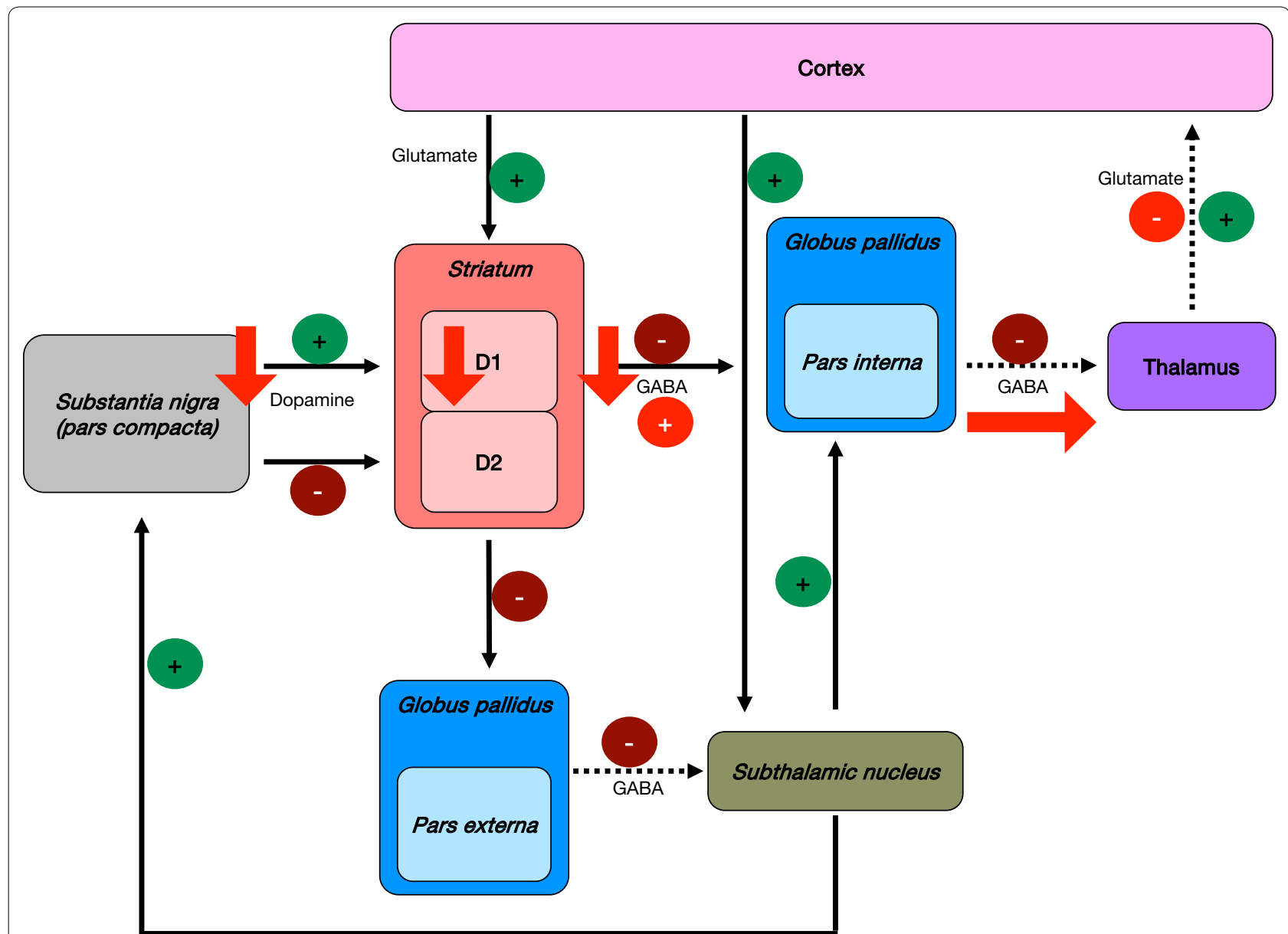

Fig. 2 Basal ganglia dysfunction and physiopathology of Parkinson's disease. The progressive loss of ascending dopaminergic projections is the key factor in the establishment of Parkinson's disease. Continuous lines represent the normal function of basal ganglia; dotted lines represent the normal function of brain segments without the previous inhibition/activation pathway; and red arrows represent the alterations in basal ganglia observed in PD

manifestations begin focally, typically in one limb segment, when dopamine concentrations fall below $60-70 \%$ in the contralateral striatum [12].

The initial pathogenesis of PD consists in a cascade of events leading to cell death, which includes oxidative stress, excitotoxicity via glutamate pathways, impaired mitochondrial functions, protein misfolding and aggregation due to ubiquitin-proteasomal system dysfunction, altered lysosome and chaperone-mediated autophagy and the development of cytoplasmic inclusion bodies (called Lewy bodies) (Fig. 3, left panel) [13]. Inflammation and humoral immune reactions may contribute to cell death processes through apoptosis [12].

Lewy bodies contain neuro-filament proteins and ubiquitinated $\alpha$-synuclein, being their presence an important factor that allows to classify pathological changes in PD progression: stage 1, involves changes in dorsal motor nucleus and olfactory bulb associated with the loss of olfactory function, commonly seen in pre-clinical PD; stage 2, includes Lewy body formation in pons and medulla; stages 3 and 4, produce clinical motor symptoms; and stages 5 and 6 , involve damage in neocortical areas, that result in cognitive problems and dementia [14].

Oxidative stress is an alteration observed in PD and other neurodegenerative diseases, e.g. amyotrophic lateral sclerosis and Alzheimer's disease. The brain is especially vulnerable to this oxidative environment, due to several factors: (1) the large fraction of oxygen consumed by this organ [15]; (2) its high metal ion levels that can react with specific reactive oxygen species (ROS) to form hydroxyl radicals responsible for the oxidative damage [16, 17]; and (3) the elevated prevalence 
Cellular and molecular mechanisms in Parkinson's disease

1. Mitochondrial function and mitophagy

$$
\begin{array}{ll}
\text { - } & \text { Parkin } \\
\text { - } & \text { DJNK1 } \\
\text { - } & \text { CHCHD2 } \\
\text { - } & \text { POLG1 } \\
\text { SREBF1 }
\end{array}
$$

2. Lysosome autophagy pathway

$$
\text { - LRRK2 }
$$

- VP35

- DNAJC13 (REM-8)

- atP13A2

- GBA

- $\quad$ SCARB (LIMP-2)

3. Ubiquitin-proteasome system

- Parkin

- FBXO7

4. Neurite structure

- LRRK2

- MAPT (tau)

5. Protein aggregation

- SNCA (a-synuclein)

- MAPT (tau)

6. Protein and membrane trafficking

- VPS35

- DNAJC13 (REM-8)

- LRRK2

- GAK

- RAB7L1

- RAB39B

7. Synaptic function and dopamine neurotransmission

- SNCA (a-synuclein)

- LRRK2

- 5 YNJ1 (synaptojanin1)

- $\mathrm{GCH} 1$

- STX1B (syntaxis-1B)

8. Prion-like transmission: - SNCA (a-synuclein)

9. Oxidative damage
Cellular and molecular mechanisms in IGF-1 deficiency

1. Mitochondrial dysfunction sensitive to IGF-1 therapy: a) decreased MMP; $b$ ) increased mitochondrial ROS production; c) reduced ATP synthesis

2. Reduced gene expression related to mitochondrial protection and cytoprotection.

- Bcl2

- Gadd45a

- Gadd45b

- Serpinb1b

- Serpinb1

3. Over expression of pro-death and pro-oxidative genes in brain of mice with IGF-1 partial deficiency.

- Ptgs2

- Nos1

- Saa1

- Crlf1

- Tgfb2

4. Mitochondrial damage and proapoptotic genes over expression.

- Bid

- Apaf1

- Grb2

- Parp1

- Ulk1

5. $\alpha$-synuclein modulation:

- Hyperexpression of $\alpha$ synuclein in mice with partial IGF-1 deficiency.

- Direct interaction of $\alpha-$ synuclein and AKT regulates IGF-1 signaling.

6. Neurotrophic factors in IGF-1 deficiency:

- Overexpression: Bdnf, Ntf3

- Reduced expression: Manf Cntf

- Reduced expression of signaling pathway gene (GDNF Family): Ret

7. Oxidative damage: Increased oxidative damage that reverted to normal by IGF-1 therapy.

Fig. 3 Parallelism between the cellular and molecular mechanisms involved in the pathogenesis of Parkinson's disease and IGF-1 deficiency (modified from Kalia et al. [8]) 
of polyunsaturated fatty acids in brain membranes, which are particularly vulnerable to oxidative damage.

Recently, several studies in animal models have shown that various neurotrophic factors, when administered exogenously, reduce the vulnerability of dopaminergic neurons. One of these factors is the glial cell line-derived neurotrophic factor (GDNF), which seems to be effective in the treatment of PD [18].

As aforementioned, age is the major known risk factor for PD. It is important to notice that endogenous levels of some neurotrophic factors decrease with age. This idea suggests that neurotrophic factors loss due to aging may contribute to the etiology of PD [19].

\section{Prevalence of Parkinson's disease}

The prevalence of PD increases with age. To date, several meta-analyses have been conducted to obtain worldwide age and sex-related estimates for PD. In 2016, approximately 6.1 million people had PD, most belonging to high and middle socio-demographic index (SDI) countries, such as North America and Canada (Table 1) [3]. This rate is 2.4 times higher than in 1990 (2.5 million people with PD). However, such increase in PD patients

Table 1 Worldwide prevalence of Parkinson's disease

\begin{tabular}{lll}
\hline Country & General population & References \\
\hline High SDI countries & 2.1 million (34.4\%) & [3] \\
High-middle or middle & 3.1 million (50.8\%) & \\
SDI countries & \\
Low SDI countries & 0.9 million (14.8\%) \\
Worldwide & $\begin{array}{l}6.1 \text { million } \\
\text { Female: } 2.9 \text { million (47.5\%) } \\
\end{array}$ & Male: 3.2 million (52.5\%) \\
\hline
\end{tabular}

SDI socio-demographic index worldwide between 1990 and 2016 is not explained entirely by the augmentation in elder people [3].

Age-standardized prevalence of PD shows that this disorder is more frequent between 65 and 79 years, especially in men, being this ratio 1.40 times higher in men than women in 2016 (Table 2) [3, 20-27]. Consequently, additionally to elder age, male sex is recognized as a prominent risk factor in the development of PD. Also, PD incidence in men continues to rise after 80 years old; being the age of PD onset about 2 years later in women than men [28].

\section{Parkinson's disease, estrogens and sex differences. Estrogen actions via IGF-1 activity in brain}

Estrogens are steroid hormones that promote female sex characteristics and reproductive capability in several organs, including brain. These hormones can cross the blood brain barrier and also the brain can endogenously produce estrogen from cholesterol [29].

Estrogens have been first identified for their role in female reproductive cycle. Nevertheless, their protective functions against chronic and degenerative diseases are becoming more relevant. These new roles may be responsible for the long-recognized advantages that women have over men in retaining their general health and achieving greater longevity [30].

Most of the circulating estrogens in premenopausal women are produced mainly by the ovaries, and in small quantities by other peripheral tissues, such as liver, adrenal gland, mammary glands, adipose tissue and brain [31]. In males, testes produce only $20 \%$ of circulating estrogens, being mostly locally produced by adipose tissue, brain, skin and bone. Herein, aromatases convert testosterone to estrogen [32].

Estrogen receptors have beneficial effects on memory and cognition, being widely distributed in male and

Table 2 Worldwide age-related prevalence of Parkinson's disease

\begin{tabular}{lll}
\hline Age-related prevalence of Parkinson's disease & \\
\hline Age & Female & Male \\
\hline $4-49$ years & 3.26 per 10,000 person-years & 3.57 per 10,000 person-years \\
$>80$ years & 103.48 per 10,000 person-years & 258.47 per 10,000 person-years \\
\hline Age of Parkinson's disease patients in countries with high prevalence of the disease & Hirsch et al. [21] \\
\hline Country & Age general population & Van Den Eeden [22] \\
\hline United States of America (USA) & 70.5 & Yamawaki et al. [26] \\
Japan & $68.7 \pm 10.3$ & Pagano et al. [24] \\
Europe & $61.6 \pm 9.73$ & Song et al. [25] \\
China & $58.7 \pm 10.55$ & Rodríguez-Violante et al. [23] \\
Mexico & $56.9 \pm 11.8$ &
\end{tabular}


female brains [33]. To date, several effects of estrogens in neurodegenerative diseases, such as PD, have been described [34]. Some of them are implicated in cognition, synaptic plasticity, memory, neurogenesis and neuroprotection [35]. Numerous studies have suggested that the molecular mechanism by which estradiol exerts its neuroprotective effects involves phosphatidyl inositol-3-kinase (PI3K) signaling pathway activation. This cascade is activated by insulin and insulin-like growth factor 1 (IGF-1) in brain [36]. As follows, there is a certain association between IGF-1 and estrogens and their protective effects exerted in nigrostriatal dopamine neurons after 6-hydroxdopamine lesions; suggesting them as an useful therapy to palliate PD symptoms [37].

In this manner, women with PD typically have a more benign phenotype with slower progression of the disease than men, and the incidence and prevalence of PD is higher in postmenopausal than in premenopausal women of similar age [38]. This could be due to the higher estrogen activity, which increases dopamine levels in the striatum, thus promoting neuron survival and neuroprotective actions [38, 39]. In addition, estrogens might prevent Lewy body deposition through specific $\alpha$-synuclein anti-aggregation and fibril destabilization properties [40]. In the last decade, the modulation of $\alpha$-synuclein aggregation is emerging as an innovative therapeutic strategy for PD treatment. In this fashion, small organic molecules, e.g. polyphenols such as curcumin, have been widely tested for their ability to inhibit $\alpha$-synuclein aggregation $[41,42]$.

Until now, estrogen deficiency has been associated with PD. In industrialized countries approximately $0.3 \%$ of the entire population and near $1 \%$ of people older than 60 years have PD related to estrogen deficiency due to loss of function mutations [43]. For example, in European countries this prevalence ranges from $65.6 / 100,000$ to $12,500 / 100,000$ people, with an incidence from 5 to 346/100,000 [44-46].

Additionally, a range of behavioral and lifestyle preferences associated with gender differences, e.g. diet, exercise, smoking and caffeine, are emerging as potential PD risk modifiers [47]. The nigrostriatal dopaminergic pathway may thus underlie the biological sex differences vulnerability, and could also be responsible for the dimorphic sexual actions of estradiol, which shelter females against striatal dopamine loss in experimental PD. However, in males such pathway fails to protect or may even worsen striatal lesions. Studies in animal models with estrogen deprivation exhibit dopaminergic neuron loss, and altered dopaminergic metabolism and transporter uptake, which can be partially reverted by exogenous estrogen administration [48]. In consequence, there is a link between longer estrogen exposure during lifetime and both decreased PD risk and milder features in women [48]. All these results open a door to potential hormone-based therapies as novel approaches to develop treatments which can delay and possibly halt the progression of the disease [27].

\section{Physiological roles of insulin-like growth factor 1}

IGF-1 is a 70-amino acid polypeptide hormone with several functions [49]. IGF-1 described roles include tissue growth and development, insulin-like activity, proliferation, pro-survival, anti-aging, antioxidant and neuroprotective, among others. Also, IGF-1 is a major relevant hormone in embryological and postnatal states [50]. Although it is mainly produced by the liver for endocrine activities, virtually every tissue is able to secrete IGF-1 for autocrine and/or paracrine purposes [51].

Until now, the best-known conditions of IGF-1 deficiency in humans are growth hormone insensitivity (GHI), advanced liver cirrhosis and aging, including cardiovascular and neurological diseases associated to aging [52]. More recently, intrauterine growth restriction [53] and metabolic syndrome [54] seem to be other forms of IGF-1 deficiency. Besides these conditions, several diseases have been recently proposed to be either consequence or cause of both systemic or local IGF-1 deficiency [52].

\section{Expression of IGF-1 in central nervous system}

IGF-1 is produced by all major central nervous system (CNS) cell types, with an area-specific pattern production, being higher in the brain stem, cerebellum, cerebral cortex and the striatum [55,56]. This hormone peaks during development, declining with age. IGF1 receptor (IGF1R) is expressed in both neural stem cells and all neural cells throughout life $[57,58]$, being highly produced among the choroid plexus, hippocampus and parahyppocampal areas [59]; but also to a less extent in the amygdala, cerebellum and cortex [60-62].

Several studies have shown that IGF-1 expression is increased in frontal cortex in PD compared to controls, while IGF1R is reduced in white matter and amygdala $[63,64]$. As aforementioned, IGF-1 levels and signaling cascade are reduced during aging, due to an increased hyper-phosphorylation of insulin receptor substrates (IRSs), one of the first proteins activated in insulin and IGF-1 pathways, thus impairing the activation of downstream molecules such as PI3K [65-67].

IGF-1 mRNA expression levels in brain are relatively low compared to IGF1R, suggesting an important role for peripheral IGF-1 [68]. It was first reported in rats more than 20 years ago that systemic IGF-1 could cross the blood-brain-barrier by transcytosis [59] and via the choroid plexus [68]. Nonetheless, there is no significant 
correlation between serum and cerebrospinal fluid IGF-1 levels and therefore, it seems that systemic IGF-1 is not a major source of IGF-1 for the CNS [69]. For this reason, the endocrine role of serum IGF-1 is still a matter of debate.

\section{IGF-1 actions in the central nervous system}

Little is known about the mechanisms that regulate IGF-1 expression in brain, but there is evidence that growth factors, nutrition, exercise and external insults (e.g. hypoxic/ischemic, demyelination, stereotactic, electrolyte and cryogenic injuries) influence IGF-1 expression in vivo [59, 70-74].

IGF-1 is a potent neuroendocrine regulator of the CNS development, maturation and plasticity [75], even being responsible for up to $40 \%$ of brain's weight [76-80]. This hormone also has a role in brain differentiation, either from mesenchymal stem cells into neuronal lineages [81] or from neural stem cells towards neuronal or glial phenotypes [81]. IGF-1 has been found to exert profound effects on neurogenesis in the developing [78] and adult [82] brain, as well as in axonal development, synaptogenesis $[68,83]$ and migration $[68,84,85]$. Similarly, IGF-1 has shown to be indispensable for exercise-induced neurogenesis [86].

Several studies have found increased IGF-1 levels in the CNS following an injury, acting as an endogenous protective mechanism [87, 88]. This is in accordance with the increased IGF-1 levels observed at the beginning of PD pathophysiology (Table 3), suggesting that those whose IGF-1 concentrations do not rise enough will present a worst outcome. Similarly, murine models of peripheral nerve injury show that erythropoietin treatment promotes peripheral nerve regeneration by upregulating IGF-1 expression [89]. For these reasons, IGF-1 could be an important factor for brain protection and injury recovery, as it stimulates cell proliferation (progenitor, neuronal and non-neuronal) as well as their incorporation into the functional brain circuit [90], together with its anti-apoptotic, pro-survival and protective features on cellular metabolism [54].

When unravelling neuronal plasticity-associated IGF-1 actions, the main mechanisms include modulation of glutamatergic receptor subunits, alterations in calcium channel conductance and potentiation of glutamatergic transmission (as a result of a reduction in GABAergic transmission) [82, 91-94]. Other mechanisms that have been proposed are the alteration in neural cell adhesion molecules and the stabilization of nascent blood vessels [95-97], in synergy with other growth factors, e.g. brainderived growth factor (BDNF, where it enhances its activation) [98] or estradiol, as estrogen-induced plasticity seems to be IGF-1 interdependent $[99,100]$.
Moreover, the correlation found between aging, where IGF-1 levels decrease (known as somatopause) and cellular processes demonstrate that IGF-1 is a vital factor for brain homeostasis, due to its well-known activities as an energy loop regulator, cell protein sorter and cell communication [101]. What is more, within the brain areas that ensue life-long neurogenesis (e.g. the dentate gyrus of the hippocampus), a $60 \%$ reduction of neuron differentiation occurs during aging. This effect could be reversed by an intracerebroventricular injection of IGF-1 [62]. In addition to the aforementioned effects, more direct IGF- 1 actions have been found in cognitive status [102, 103], amyloid clearance [70], resilience to insults [70] and behavior [104-106].

As it is known, astrocytes are the most abundant cell type in brain (the ratio astrocyte:neuron is 10:1), and the neuronal soma is entirely surrounded by astrocytic membranes [107]. For this reason, effects of a given molecule have to be determined, not only in neurons but in the entire web, particularly in astrocytes, in order to avoid overlooking results mediated through them. In this sense, astrocytes express IGF1R in the developing brain [107], and to a less extent in the adult [58], hence activating IGF-1 activities, such as proliferation [108], growth factor production [109, 110], cytoskeletal protein levels [108], intercellular communication and messengers [111-113], glutamate transport [114], glucose metabolism [115117], and mitochondrial and membrane enzyme activity $[118,119]$.

The role of IGF-1 in adult astrocytes seems to be limited to modulate tissue damage response, where reactive astrocytes express high levels of IGF1R [120, 121] and IGF-1 [122]. Likewise, hepatocytes in damaged liver express IGF1R, a circumstance not observed under normal conditions [123-125]. In this context, proinflammatory signals activate astrocytes, turning them into activated pro-inflammatory cells that will secrete several factors (e.g. inducible nitric oxide synthase 2 -iNOS2-, cyclooxygenase 2 -Cox2-, tumor necrosis factor $\alpha-\mathrm{TNF}-\alpha-$, etc.) contributing to neuron damage. IGF-1 anti-inflammatory capabilities transform these cells into anti-inflammatory ones, ceasing to produce proinflammatory signals and thus, enhance the production of neuroprotective molecules, such as humoral superoxide dismutase (SOD), neurotrophic factors, etc. Both anti- and pro-inflammatory cell types converge on the phosphatase calcineurin, that turns gene expression to one of this phenotypes [126]. Moreover, it has also been reported a neuroprotective role for IGF-1 associated to mitochondrial protection and antioxidant defenses in aging animals [127].

Data from our group suggest that the mere partial IGF-1 deficiency in mice (heterozygous mice, Igf1 ${ }^{+/-}$, 


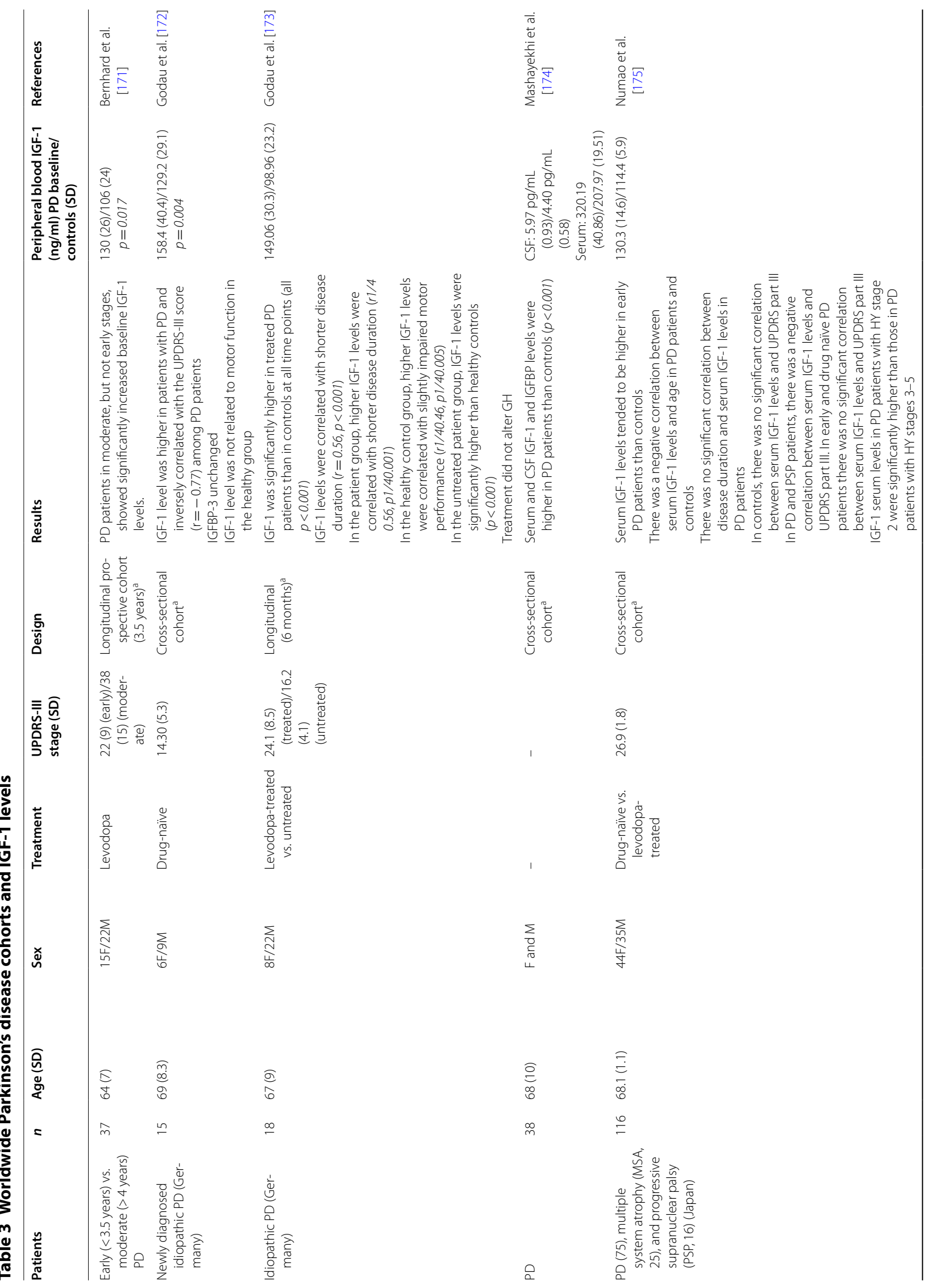




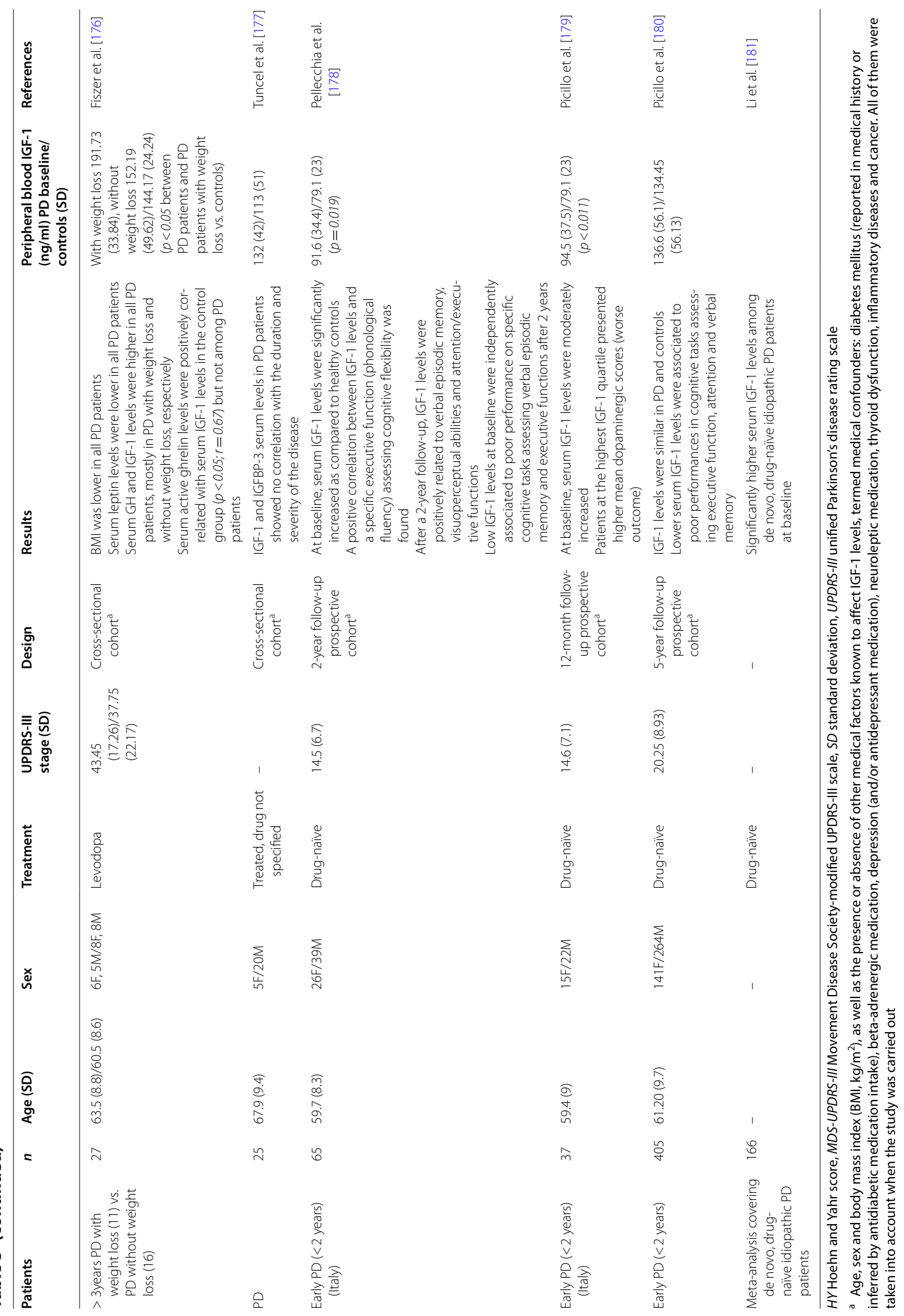


where one of the alleles of the Igf1 gene is disrupted) [128] increased brain oxidative damage, inflammation, edema, apoptosis and impaired learning and memory capabilities; being all these alterations restored by IGF-1 replacement therapy [129]. Consistently, these IGF-1 deficient mice have an alteration in the blood-brain barrier due to a distorted genetic expression of extracellular matrix and intercellular adhesion proteins (unpublished data). Furthermore, IGF-1 deficiency showed in this experimental model, an altered gene expression pattern encoding neurotrophic factors and their receptors [130].

While most of the results found in the literature have been discovered using in vitro studies, other were discovered using animal models of CNS injury or IGF-1 deficiency. Even though these experimental models have been really advantageous in unravelling the neurobiology of IGF-1, clinical data is very scarce and so is our understanding of its therapeutic potential. Nevertheless, tremendous possibilities have been appointed towards its usage. Herein we will focus on PD; however, the degenerative neurological conditions with the larger impact on population have been somehow linked with IGF-1 alterations [131-134].

\section{Neurodegenerative diseases related to aging as IGF-1 deficiency conditions}

An increasing number of disorders have been reported highlighting the role of IGF-1 in many different organs and system functions. The knowledge concerning "IGF-1 deficiency conditions" or "GHI", in which replacement therapy could be considered as an effective therapeutic strategy, is only recent.

The best-known condition of IGF-1 deficiency is Laron syndrome (also known as Laron dwarfism or GHI) [135, 136], predominantly found in children, characterized by alterations in growth hormone receptors (GHR) in the liver, and hence, reducing IGF-1 synthesis. In these patients, IGF-1 replacement therapy improves growth and development $[137,138]$.

Another IGF-1 deficiency condition, in this case in adults, is liver cirrhosis [139], where decreased IGF-1 serum levels were found in these patients. However, during the last decade, our research team has disclosed the causal link between IGF-1 deficiency and the severe malnutrition syndrome associated to liver cirrhosis progression. In fact, the exogenous administration of low doses of IGF-1 in experimental cirrhosis improved nutritional status and nitrogen balance [140], intestinal absorption [141-144], osteopenia [145, 146], testicular atrophy [147, 148], restored somatostatinergic tone controlling growth hormone (GH) secretion [149] and induced hepatoprotective actions in the liver associated with a reduction in oxidative damage and enhancing mitochondrial protection [150-153]. In addition, IGF-1 replacement therapy increased albumin circulating levels in cirrhotic patients [154].

Thirdly, aging may be considered as a recognized IGF-1 deficiency condition [155-157]. Although several studies have suggested that reduced GH/IGF-1 activity promotes longevity [158-160], a significant amount of evidence indicates that IGF-1 might play a role in several pathological conditions [102, 161-165] commonly seen during aging, associated with oxidative tissue damage. Precisely, several reports suggest that age-related changes in cellular and tissue function are linked to a decrease in anabolic hormones, GH and IGF-1 levels [155-157, 166]. Accordingly, previous studies from our group reported that administration of low doses of IGF-1 in aging rats improved glucose and lipid metabolism, reducing insulin resistance, increased testosterone levels and serum total antioxidant capability of the cell, and reduced oxidative damage in brain and liver, all of them associated with a normalization of antioxidant enzyme activities and mitochondrial function $[167,168]$.

In addition to these well-known IGF-1 deficiency conditions and its correlation with aging and cognition, several neurodegenerative disorders show low IGF-1 serum levels, such as PD, Alzheimer's disease and cerebrovascular disease [132, 134]. Conversely, several neurodegenerative diseases, with the exception of PD, exhibit reduced $\mathrm{GH}$-stimulation test response (with clonidine, arginine and growth hormone stimulating hormone, GHRH) [169]. This result could partly explain why in PD, high serum levels of IGF-1 are found (Table 3), in opposition with its related diseases. Moreover, a study disclosed that 5-HT 1-receptor-mediated growth hormone secretion neurotransmission was absent in PD patients, suggesting an alteration in serotonin signaling [170].

As described before, the GH/IGF-1 axis is involved in brain development, growth and function; so its progressive decrease during aging could be embroiled in the establishment of several human cerebrovascular diseases, that lead to neuronal degeneration and dysfunction, such as PD, multiple system atrophy, Lewy body disease, Alzheimer's disease, vascular dementia, amyotrophic lateral sclerosis, stroke, etc. [131-133].

\section{Theoretical relationship between Parkinson's disease and IGF-1 deficiency}

Noticeably, there is a clear relationship between IGF-1 and PD (Fig. 3). The preclinical data presented in this review strongly suggests a neuroprotective role for IGF-1. As Table 3 depicts, IGF-1 levels in almost all PD cohorts are higher in both sera and cerebrospinal fluid of these patients, particularly at the symptom's onset (UPDRSIII) and then equals out as the disease progresses. 
These IGF-1 concentrations inversely correlate with the UPDRS-III score (i.e. with motor function), verbal episodic memory, visuoperceptual abilities and attention/ executive functions; been not found such correlation on healthy subjects [171-181]. As it has been shown, lower IGF-1 levels at the beginning of PD are associated with a worse disease progression and prognosis. However, IGF-1 correlation with the disease onset, duration, severity, etc., still remains a hot topic.

Few genetic alterations have been linked to PD, being the most common the so-called idiopathic PD. Among them are mutations affecting a-synuclein [182-184], which leads to familial PD. However, the exact role of a-synuclein in the pathophysiology of PD, besides its aggregation to form Lewy bodies, remains unclear [185]. Recently, a-synuclein has been found to be essential for IGF-1 and other neurotrophic factors signaling activation in brain via protein kinase B (PKB or Akt). Actually, it has been hypothesized that a-synuclein long-unknown role in brain could be to transport, localize and solubilize Akt for neurotrophic factor receptors in brain cells [186]. In vitro studies have disclosed that decreased Akt phosphorylation due to lack of functional a-synuclein lead to poor IGF-1 signaling in neuronal and non-neuronal cells. This molecule, Akt, is a key survival signaling mediator of IGF1R in all cells, suggesting that IGF-1 protective effects in brain could be halted at the PD etiology itself.

Also, it has been proved that a-synuclein aggregation neurotoxicity is mediated by dopamine, and that IGF-1 confers protection against such aggregation and promotes signaling rescue through Akt, even in presence of dopamine [187]. Of interest, a recent study found an accurate micro-RNA profile alteration in post-mortem microdissected dopaminergic neurons. In this study, miR-126 particularly blocked IGF-1 signaling pathway, increasing cell vulnerability to 6-hydroxydopamine neurotoxicity [188]. In consequence, all this data demonstrates that cell response capability is decreased may be due to a-synuclein, miR-126, or dopamine cytotoxicity, dysregulating IGF-1 signaling pathway that lead to cell death and neurodegenerative features observed during the course of PD.

Several epidemiological studies have demonstrated a significantly increased risk for developing PD in individuals with central obesity [189, 190], an important result because IGF-1 and insulin signaling pathways are known to be dysregulated under metabolic derangements [54]. This suggests that insulin/IGF-1 signaling deficit could decrease neuroprotection and render the brain vulnerable to oxidative damage [191]. Furthermore, epidemiological studies have shown an association between the exposure to environmental toxins and an increasing incidence of PD in younger people [192-194]. Modern era exposure to toxins causes an elevated chronic grade of inflammation, alike obesity, that in turn antagonizes insulin/IGF-1 signaling, generating resistance and rendering the body without its physiological, trophic and protective effects. This assertion has been recently intimately linked to cardiovascular diseases [195].

As aforementioned, results from PD cohorts illustrated in Table 3 shows that lower IGF-1 levels at the beginning of the disease are associated with a worse progression and prognosis, being IGF-1 concentrations higher in PD cohorts at the symptom's onset. These data could act as a compensatory mechanism due to the lack of IGF-1 signaling feedback and, also, it could be an endogenous protective factor released in response to cell death and oxidative damage promoted by the disease itself. Such hypothesis is further sustained by a progressive PD model study where IGF-1 was found to protect the nigrostriatal pathway, and that this protection was preceded by activations of key pro-survival signaling cascades, such as Akt $[181,196]$.

\section{Conclusions}

There are strong lines of evidence to correlate IGF-1 with PD establishment and development. Herein, the present review tries to summarize how IGF-1 and estrogen levels, together with their neuroprotective and anti $\alpha$-synuclein aggregation properties, act in a harmonized manner to maintain brain homeostasis, particularly during aging process. From our experience, the mere partial IGF-1 deficiency in a murine model increases brain oxidative damage, inflammation, edema and apoptosis, also impairing learning and memory capabilities and the blood-brain barrier integrity. All these alterations are restored by exogenous IGF-1 replacement therapy.

As it is known, the pathogenesis of PD, the second most common neurodegenerative disorder, consists in a cascade of events including oxidative stress, excitotoxicity via glutamate pathways, impaired mitochondrial functions, protein misfolding and aggregation due to ubiquitin-proteasomal system dysfunction, altered lysosome and chaperone-mediated autophagy and the development of cytoplasmic Lewy bodies, eventually leading to cell death. Due to its neuroprotective functions, in the last decade several studies have been conducted in order to understand and resolve the linkage between IGF-1 and PD. In this way, numerous basic and translational reports have appointed brain protection and injury recovery functions of IGF-1 in CNS injuries and/or PD patients. These results highlight the protective and homeostatic key roles of IGF-1 in brain, along with its anti-apoptotic, pro-survival and protective features on cellular metabolism. 
The aging process, where IGF-1 serum levels decrease with age, is one of the risk factors for PD development. However, several clinical correlations in PD patients have reported an augmentation in IGF-1 levels at the onset of the disease, which suggests, given the preclinical results, an ongoing compensatory or "fight-toinjury" mechanism, since as the disease progresses such elevation dissipates. Additionally, lower IGF-1 levels at the beginning of PD are associated with a worse disease progression and prognosis.

Together with age, male sex is another crucial risk factor for PD establishment. Estrogens seem to confer women a strong protection to PD due to their beneficial effects on memory and cognition. This estrogen related neuroprotection is achieved via IGF-1 signaling pathway, as estrogens activate PI3K to stimulate neuron survival and protection. Nevertheless, more experimental studies need to be performed to better understand the molecular mechanisms from IGF-1 cascade involved in PD.

In this fashion, it could be reasonable to think in a combined therapy with estrogens and IGF-1, since both molecules can cross the blood-brain barrier activating the IGF-1 signaling pathway to exert its favorable actions in brain and also to prevent $\alpha$-synuclein aggregation (Lewy body deposition), thus avoiding PD development. This hypothesis is in accordance with recent studies where polyphenols, such as curcumin, are used to inhibit $\alpha$-synuclein aggregation and prevent oxidative damage related alterations. Also, GDNF, a neurotrophic factor, could be used as a therapy for PD, because it can reduce the vulnerability of domapinergic neurons. However, in order to solve this question, more cexperimental and clinical studies need to be done.

\begin{abstract}
Abbreviations
BDNF: brain-derived growth factor; CNS: central nervous system; Cox2: cyclooxygenase 2; GABA: gamma-aminobutyric acid; GDNF: glial cell linederived neurotrophic factor; GH: growth hormone; GHI: growth hormone insensitivity; GHR: growth hormone receptor; GHRH: growth hormone releasing hormone; IGF-1: insulin-like growth factor 1; IGF1R: IGF-1 receptor; iNOS2: inducible nitric oxide synthase 2; IRSs: insulin receptor substrates; PD: Parkinson's disease; PI3K: phosphatidyl inositol-3-kinase; PKB: protein kinase B; ROS: reactive oxygen species; SDI: socio-demographic index; SOD: superoxide dismutase; TNF-a: tumor necrosis factor a.
\end{abstract}

\section{Acknowledgements}

The authors would like to express their gratitude to Dr. Leonel Cantú and Dr. Mariano García-Magariño Alonso for their invaluable help. This work was possible thank to the financial help of "Fundación de Investigación HM Hospitales" and "Tecnológico de Monterrey".

\section{Authors' contributions}

GAA, GFR, LE and IME participated in compiling data and elaborating the manuscript. ICC designed the review content, contributed to its writing and revised the conceptual contents until the final approval. All authors read and approved the final manuscript.
Funding

Not applicable.

Availability of data and materials

Not applicable.

Ethics approval and consent to participate

Not applicable.

\section{Consent for publication}

Not applicable.

\section{Competing interests}

The authors declare that they have no competing interests.

\section{Author details}

${ }^{1}$ Tecnologico de Monterrey, Escuela de Medicina y Ciencias de la Salud, Ave. Morones Prieto 3000, 64710 Monterrey, N.L., Mexico. ${ }^{2}$ Fundación de Investigación HM Hospitales, Madrid, Spain. ${ }^{3}$ Centre for Tumour Biology, Barts Cancer Institute, Barts and The London School of Medicine and Dentistry, Queen Mary University of London, London, UK. ${ }^{4}$ Neurocenter, Monterrey, Nuevo Leon, Mexico.

Received: 23 August 2019 Accepted: 10 January 2020

Published online: 11 February 2020

\section{References}

1. Goetz CG. Charcot on Parkinson's disease. Mov Disord. 1986;1(1):27-32.

2. Erkkinen MG, Kim M-O, Geschwind MD. Clinical neurology and epidemiology of the major neurodegenerative diseases. Cold Spring Harb Perspect Biol. 2018;10(4):a033118.

3. GBD 2016 Parkinson's Disease Collaborators. Global, regional, and national burden of Parkinson's disease, 1990-2016: a systematic analysis for the Global Burden of Disease Study 2016. Lancet Neurol. 2018;17(11):939-53.

4. Jankovic J. Parkinson's disease: clinical features and diagnosis. J Neurol Neurosurg Psychiatry. 2008;79(4):368-76.

5. Rodriguez-Oroz MC, Jahanshahi M, Krack P, Litvan I, Macias R, Bezard E, et al. Initial clinical manifestations of Parkinson's disease: features and pathophysiological mechanisms. Lancet Neurol. 2009;8(12):1128-39.

6. Olanow CW, Obeso JA. The significance of defining preclinical or prodromal Parkinson's disease. Mov Disord. 2012;27(5):666-9. https://doi. org/10.1002/mds.25019.

7. Antony PMA, Diederich NJ, Krüger R, Balling R. The hallmarks of Parkinson's disease. FEBS J. 2013;280(23):5981-93. https://doi.org/10.1111/ febs. 12335

8. Kalia LV, Lang AE. Parkinson's disease. Lancet. 2015;386(9996):896-912.

9. Berg D, Lang AE, Postuma RB, Maetzler W, Deuschl G, Gasser T, et al. Changing the research criteria for the diagnosis of Parkinson's disease: obstacles and opportunities. Lancet Neurol. 2013;12(5):514-24.

10. Dirnberger $\mathrm{G}$, Jahanshahi M. Executive dysfunction in Parkinson's disease: a review. J Neuropsychol. 2013;7(2):193-224. https://doi. org/10.1111/jnp.12028.

11. Juri C, Rodríguez-Oroz MC, Burguera JA, Guridi J, Obeso JA. Pain and dyskinesia in Parkinson's disease. Mov Disord. 2010;25(1):130-2.

12. Sabatini U, Boulanouar K, Fabre N, Martin F, Carel C, Colonnese C, et al. Cortical motor reorganization in akinetic patients with Parkinson's disease: a functional MRI study. Brain. 2000;123(Pt 2):394-403.

13. Olanow CW. The pathogenesis of cell death in Parkinson's disease-2007. Mov Disord. 2007;22(SUPPL. 17):S335-42.

14. Braak H, Ghebremedhin E, Rüb U, Bratzke H, Del Tredici K. Stages in the development of Parkinson's disease-related pathology. Cell Tissue Res. 2004;318(1):121-34.

15. Mink JW, Blumenschine RJ, Adams DB. Ratio of central nervous system to body metabolism in vertebrates: its constancy and functional basis. Am J Physiol. 1981:241(3):R203-12.

16. Connor JR, Benkovic SA. Iron regulation in the brain: histochemical, biochemical, and molecular considerations. Ann Neurol. 1992;32(Suppl):S51-61. 
17. Mills E, Dong X-P, Wang F, Xu H. Mechanisms of brain iron transport: insight into neurodegeneration and CNS disorders. Future Med Chem. 2010;2(1):51-64

18. Patel NK, Pavese N, Javed S, Hotton GR, Brooks DJ, Gill SS. Benefits of putaminal GDNF infusion in Parkinson disease are maintained after GDNF cessation. Neurology. 2013;81(13):1176-8.

19. Parain K, Murer MG, Yan Q, Faucheux B, Agid Y, Hirsch E, et al. Reduced expression of brain-derived neurotrophic factor protein in Parkinson's disease substantia nigra. Neuroreport. 1999;10(3):557-61.

20. Pringsheim T, Jette N, Frolkis A, Steeves TDL. The prevalence of Parkinson's disease: a systematic review and meta-analysis. Mov Disord. 2014;29(13):1583-90.

21. Hirsch L, Jette N, Frolkis A, Steeves T, Pringsheim T. The incidence of Parkinson's disease: a systematic review and meta-analysis. Neuroepidemiology. 2016;46(4):292-300.

22. Van Den Eeden SK. Incidence of Parkinson's disease: variation by age, gender, and race/ethnicity. Am J Epidemiol. 2003;157(11):1015-22.

23. Rodríguez-Violante M, Villar-Velarde A, Valencia-Ramos C, CervantesArriaga A. Características epidemiológicas de pacientes con enfermedad de Parkinson Arch Neurocien (Mex) INNN. Arch Neurocien. 2011;16:64-8

24. Pagano G, Ferrara N, Brooks DJ, Pavese N. Age at onset and Parkinson disease phenotype. Neurology. 2016;86(15):1400-7.

25. Song Y, Gu Z, An J, Chan P. Gender differences on motor and non-motor symptoms of de novo patients with early Parkinson's disease. Neurol Sci. 2014;35(12):1991-6.

26. Yamawaki M, Kusumi M, Kowa H, Nakashima K. Changes in prevalence and incidence of Parkinson's disease in Japan during a quarter of a century. Neuroepidemiology. 2009;32(4):263-9.

27. Gillies GE, Pienaar IS, Vohra S, Qamhawi Z. Sex differences in Parkinson's disease. Front Neuroendocrinol. 2014;35(3):370-84.

28. Alves G, Müller B, Herlofson K, HogenEsch I, Telstad W, Aarsland D, et al. Incidence of Parkinson's disease in Norway: the Norwegian ParkWest study. J Neurol Neurosurg Psychiatry. 2009;80(8):851-7.

29. Kuiper GGJM, Carlsson B, Grandien K, Enmark E, Häggblad J, Nilsson $S$, et al. Comparison of the ligand binding specificity and transcript tissue distribution of estrogen receptors $a$ and $\beta$. Endocrinology. 1997;138(3):863-70.

30. Murphy E. Estrogen signaling and cardiovascular disease. Circ Res. 2011;109(6):687-96

31. Barakat R, Oakley O, Kim H, Jin J, Ko CJ. Extra-gonadal sites of estrogen biosynthesis and function. BMB Rep. 2016:49(9):488-96.

32. Vermeulen A, Kaufman JM, Goemaere S, Van Pottelberg I. Estradiol in elderly men. Aging Male. 2002;5(2):98-102.

33. Bean LA, lanov L, Foster TC. Estrogen receptors, the hippocampus, and memory. Neurosci. 2014;20(5):534-45. https://doi.org/10.1177/10738 58413519865

34. Gaignard P, Liere P, Thérond P, Schumacher M, Slama A, Guennoun R. Role of sex hormones on brain mitochondrial function, with special reference to aging and neurodegenerative diseases. Front Aging Neurosci. 2017;9:406.

35. Mcmahon T, Van Zijl PCM, Gilad AA. NIH Public Access. 2015;27(3):320-31.

36. González C, Díaz F, Alonso A. Neuroprotective effects of estrogens: cross-talk between estrogen and intracellular insulin signalling. Infect Disord Drug Targets. 2008;8(1):65-7.

37. Quesada A, Micevych PE. Estrogen interacts with the IGF-1 system to protect nigrostriatal dopamine and maintain motoric behavior after 6-hydroxdopamine lesions. J Neurosci Res. 2004;75(1):107-16. https:// doi.org/10.1002/jnr.10833.

38. Labandeira-Garcia JL, Rodriguez-Perez Al, Valenzuela R, Costa-Besada MA, Guerra MJ. Menopause and Parkinson's disease. Interaction between estrogens and brain renin-angiotensin system in dopaminergic degeneration. Front Neuroendocrinol. 2016;2016(43):44-59.

39. Haaxma CA, Bloem BR, Borm GF, Oyen WJG, Leenders KL, Eshuis S, et al. Gender differences in Parkinson's disease. J Neurol Neurosurg Psychiatry. 2007;78(8):819-24.

40. Hirohata M, Ono K, Morinaga A, Ikeda T, Yamada M. Anti-aggregation and fibril-destabilizing effects of sex hormones on a-synuclein fibrils in vitro. Exp Neurol. 2009;217(2):434-9.
41. Zhang G, Xia Y, Wan F, Ma K, Guo X, Kou L, et al. New perspectives on roles of alpha-synuclein in Parkinson's disease. Front Aging Neurosci. 2018;22:10. https://doi.org/10.3389/fnagi.2018.00370/full.

42. Singh SK, Dutta A, Modi G. a-Synuclein aggregation modulation: an emerging approach for the treatment of Parkinson's disease. Future Med Chem. 2017;9(10):1039-53. https://doi.org/10.4155/ fmc-2017-0016.

43. Nussbaum RL, Ellis CE. Alzheimer's disease and Parkinson's Disease. N Engl J Med. 2003;348:1356-64.

44. Tanner CM, Goldman SM. Epidemiology of Parkinson's disease. Neurol Clin. 1996:14(2):317-35.

45. Tanner CM. Epidemiology of Parkinson's disease. Neurol Clin. 1992;10(2):317-29.

46. Von Campenhausen S, Bornschein B, Wick R, Bötzel K, Sampaio C, Poewe W, et al. Prevalence and incidence of Parkinson's disease in Europe. Eur Neuropsychopharmacol. 2005;15(4):473-90.

47. Picillo M, Nicoletti A, Fetoni V, Garavaglia B, Barone P, Pellecchia MT. The relevance of gender in Parkinson's disease: a review. J Neurol. 2017;264(8):1583-607.

48. Smith KM, Dahodwala N. Sex differences in Parkinson's disease and other movement disorders. Exp Neurol. 2014;259:44-56.

49. Le Roith D. Seminars in medicine of the Beth Israel Deaconess Medical Center. Insulin-like growth factors. N Engl J Med. 1997;336(9):633-40.

50. Martín-Estal I, De la Garza R, Castilla-Cortazar I. Intrauterine Growth Retardation (IUGR) as a novel condition deficiency of Insulin-like growth. Retard Intrauter Growth. 2015;1(1):1.

51. D'Ercole AJ, Applewhite GT, Underwood LE. Evidence that somatomedin is synthesized by multiple tissues in the fetus. Dev Biol. 1980;75:315-28.

52. Puche JE, Castilla-Cortázar I. Human conditions of insulin-like growth factor-I (IGF-I) deficiency. J Transl Med. 2012;10:224.

53. Martín-Estal I, de la Garza RG, Castilla-Cortázar I. Intrauterine growth retardation (IUGR) as a novel condition of insulin-like growth factor-1 (IGF-1) deficiency. Rev Physiol Biochem Pharmacol. 2016;4(170):1-35.

54. Aguirre GA, De Ita JR, de la Garza RG, Castilla-Cortazar I. Insulin-like growth factor-1 deficiency and metabolic syndrome. J Transl Med. 2016;14(1):3.

55. Bondy CA, Lee WH. Patterns of insulin-like growth factor and IGF receptor gene expression in the brain. Functional implications. Ann NY Acad Sci. 1993;692:33-43.

56. Bach MA, Shen-Orr Z, Lowe WL, Roberts CT, LeRoith D. Insulin-like growth factor I mRNA levels are developmentally regulated in specific regions of the rat brain. Brain Res Mol Brain Res. 1991;10(1):43-8.

57. Popken GJ, Dechert-Zeger M, Ye P, D'Ercole AJ. Brain development. Adv Exp Med Biol. 2005;567:187-220.

58. Baron-Van Evercooren A, Olichon-Berthe C, Kowalski A, Visciano G, Van Obberghen E. Expression of IGF-I and insulin receptor genes in the rat central nervous system: a developmental, regional, and cellular analysis. J Neurosci Res. 1991;28(2):244-53.

59. Reinhardt RR, Bondy CA. Insulin-like growth factors cross the bloodbrain barrier. Endocrinology. 1994;135(5):1753-61.

60. Gong X, Ma M, Fan X, Li M, Liu Q, Liu X, et al. Down-regulation of IGF-1/ IGF-1R in hippocampus of rats with vascular dementia. Neurosci Lett. 2012;513(1):20-4.

61. Sonntag WE, Ramsey M, Carter CS. Growth hormone and insulin-like growth factor-1 (IGF-1) and their influence on cognitive aging. Ageing Res Rev. 2005;4(2):195-212.

62. Adem A, Jossan SS, D'Argy R, Gillberg PG, Nordberg A, Winblad B, et al. Insulin-like growth factor 1 (IGF-1) receptors in the human brain: quantitative autoradiographic localization. Brain Res. 1989;503(2):299-303.

63. Lewitt MS, Boyd GW. The role of insulin-like growth factors and insulinlike growth factor-binding proteins in the nervous system. Biochem Insights. 2019;17(12):117862641984217. https://doi.org/10.1177/11786 26419842176.

64. Tong M, Dong M, de la Monte SM. Brain insulin-like growth factor and neurotrophin resistance in Parkinson's disease and dementia with Lewy bodies: potential role of manganese neurotoxicity. J Alzheimers Dis. 2009;16(3):585-99.

65. Yang $L$, Wang $H$, Liu L, Xie A. The role of insulin/IGF-1/PI3K/Akt/GSK3 $\beta$ signaling in Parkinson's disease dementia. Front Neurosci. 2018;20:12. https://doi.org/10.3389/fnins.2018.00073/full. 
66. Morris JK, Zhang H, Gupte AA, Bomhoff GL, Stanford JA, Geiger PC. Measures of striatal insulin resistance in a 6-hydroxydopamine model of Parkinson's disease. Brain Res. 2008;1240:185-95.

67. Talbot K, Wang H-Y, Kazi H, Han L-Y, Bakshi KP, Stucky A, et al. Demonstrated brain insulin resistance in Alzheimer's disease patients is associated with IGF-1 resistance, IRS-1 dysregulation, and cognitive decline. J Clin Investig. 2012:122(4):1316-38.

68. Fernandez AM, Torres-Alemán I. The many faces of insulin-like peptide signalling in the brain. Nat Rev Neurosci. 2012;13(4):225-39.

69. Bäckström M, Hall K, Sara V. Somatomedin levels in cerebrospinal fluid from adults with pituitary disorders. Acta Endocrinol. 1984;107(2):171-8.

70. Carro E, Trejo JL, Gomez-Isla T, LeRoith D, Torres-Aleman I. Serum insulin-like growth factor I regulates brain amyloid-beta levels. Nat Med. 2002:8:1390-7.

71. Kalmar B, Greensmith L. Induction of heat shock proteins for protection against oxidative stress. Adv Drug Deliv Rev. 2009;61(4):310-8.

72. Garcia-Fernandez M, Sierra I, Puche JE, Guerra L, Castilla-Cortazar I. Liver mitochondrial dysfunction is reverted by insulin-like growth factor II (IGF-II) in aging rats. J Transl Med. 2011;9:123.

73. Castilla-Cortázar I, García-Fernández M, Delgado G, Puche JE, Sierra I, Barhoum R, et al. Hepatoprotection and neuroprotection induced by low doses of IGF-II in aging rats. J Transl Med. 2011;9:103.

74. Duffy KR, Pardridge WM, Rosenfeld RG. Human blood-brain barrier insulin-like growth factor receptor. Metabolism. 1988;37(2):136-40.

75. Dyer AH, Vahdatpour C, Sanfeliu A, Tropea D. The role of Insulin-Like Growth Factor 1 (IGF-1) in brain development, maturation and neuroplasticity. Neuroscience. 2016:325:89-99.

76. Joseph D'Ercole A, Ye P. Minireview: expanding the mind: insulinlike growth factor I and brain development. Endocrinology. 2008;149(12):5958-62.

77. Ye P, Li L, Richards RG, DiAugustine RP, D'Ercole AJ. Myelination is altered in insulin-like growth factor-I null mutant mice. J Neurosci. 2002;22(14):6041-51.

78. Popken GJ, Hodge RD, Ye P, Zhang J, Ng W, O'Kusky JR, et al. In vivo effects of insulin-like growth factor-I (IGF-I) on prenatal and early postnatal development of the central nervous system. Eur J Neurosci. 2004;19(8):2056-68

79. Ye P, D'Ercole AJ. Insulin-like growth factor actions during development of neural stem cells and progenitors in the central nervous system. J Neurosci Res. 2006;83(1):1-6.

80. O'Kusky J, Ye P. Neurodevelopmental effects of insulin-like growth factor signaling. Front Neuroendocrinol. 2012;33(3):230-51.

81. Huat TJ, Khan AA, Pati S, Mustafa Z, Abdullah JM, Jaafar H. IGF-1 enhances cell proliferation and survival during early differentiation of mesenchymal stem cells to neural progenitor-like cells. BMC Neurosci. 2014;15:91.

82. Aberg ND, Brywe KG, Isgaard J. Aspects of growth hormone and insulinlike growth factor-I related to neuroprotection, regeneration, and functional plasticity in the adult brain. Sci World J. 2006;6:53-80.

83. O'Kusky JR, Ye P, D'Ercole AJ. Insulin-like growth factor-I promotes neurogenesis and synaptogenesis in the hippocampal dentate gyrus during postnatal development. J Neurosci. 2000;20(22):8435-42.

84. Hurtado-Chong A, Yusta-Boyo MJ, Vergaño-Vera E, Bulfone A, de Pablo F, Vicario-Abejón C. IGF-I promotes neuronal migration and positioning in the olfactory bulb and the exit of neuroblasts from the subventricular zone. Eur J Neurosci. 2009;30(5):742-55.

85. Oishi K, Watatani K, Itoh Y, Okano H, Guillemot F, Nakajima K, et al. Selective induction of neocortical GABAergic neurons by the PDK1Akt pathway through activation of Mash1. Proc Natl Acad Sci USA 2009:106(31):13064-9.

86. Trejo JL, Llorens-Martín MV, Torres-Alemán I. The effects of exercise on spatial learning and anxiety-like behavior are mediated by an IGF-Idependent mechanism related to hippocampal neurogenesis. Mol Cell Neurosci. 2008:37(2):402-11.

87. Madathil SK, Evans HN, Saatman KE. Temporal and regional changes in IGF-1/IGF-1R signaling in the mouse brain after traumatic brain injury. J Neurotrauma. 2010;27(1):95-107.

88. Sandberg Nordqvist AC, von Holst H, Holmin S, Sara VR, Bellander BM, Schalling M. Increase of insulin-like growth factor (IGF)-1, IGF binding protein-2 and -4 mRNAs following cerebral contusion. Brain Res Mol Brain Res. 1996:38(2):285-93.
89. Wang W, Li D, Li Q, Wang L, Bai G, Yang T, et al. Erythropoietin promotes peripheral nerve regeneration in rats by upregulating expression of insulin-like growth factor-1. Arch Med Sci. 2015;11(2):433-7.

90. Isgaard J, Aberg D, Nilsson M. Protective and regenerative effects of the GH/IGF-I axis on the brain. Minerva Endocrinol. 2007:32(2):103-13.

91. Corvin AP, Molinos I, Little G, Donohoe G, Gill M, Morris DW, et al. Insulin-like growth factor 1 (IGF1) and its active peptide (1-3)IGF1 enhance the expression of synaptic markers in neuronal circuits through different cellular mechanisms. Neurosci Lett. 2012;520(1):51-6.

92. Llorens-Martín M, Torres-Alemán I, Trejo JL. Mechanisms mediating brain plasticity: IGF1 and adult hippocampal neurogenesis. Neuroscientist. 2009;15(2):134-48.

93. Tropea D, Kreiman G, Lyckman A, Mukherjee S, Yu H, Horng S, et al. Gene expression changes and molecular pathways mediating activitydependent plasticity in visual cortex. Nat Neurosci. 2006;9(5):660-8.

94. Torres-Aleman I. Insulin-like growth factors as mediators of functional plasticity in the adult brain. Horm Metab Res. 1999;31(2-3):114-9.

95. Jacobo SMP, Kazlauskas A. Insulin-like growth factor 1 (IGF-1) stabilizes nascent blood vessels. J Biol Chem. 2015;290(10):6349-60.

96. Bonfanti L. PSA-NCAM in mammalian structural plasticity and neurogenesis. Prog Neurobiol. 2006;80(3):129-64.

97. Monzo HJ, Park TIH, Dieriks BV, Jansson D, Faull RLM, Dragunow M, et al. Insulin and IGF1 modulate turnover of polysialylated neural cell adhesion molecule (PSA-NCAM) in a process involving specific extracellular matrix components. J Neurochem. 2013;126(6):758-70.

98. McCusker RH, McCrea K, Zunich S, Dantzer R, Broussard SR, Johnson RW, et al. Insulin-like growth factor-I enhances the biological activity of brain-derived neurotrophic factor on cerebrocortical neurons. J Neuroimmunol. 2006;179(1-2):186-90.

99. Mendez P, Azcoitia I, Garcia-Segura LM. Interdependence of oestrogen and insulin-like growth factor-l in the brain: potential for analysing neuroprotective mechanisms. J Endocrinol. 2005;185(1):11-7.

100. Cardona-Gómez GP, Trejo JL, Fernandez AM, Garcia-Segura LM. Estrogen receptors and insulin-like growth factor-I receptors mediate estrogen-dependent synaptic plasticity. NeuroReport. 2000;11(8):1735-8.

101. Trejo JL, Carro E, Lopez-Lopez C, Torres-Aleman I. Role of serum insulinlike growth factor I in mammalian brain aging. Growth Horm IGF Res. 2004;14(Suppl A):S39-43.

102. Svensson J, Diez M, Engel J, Wass C, Tivesten A, Jansson J-O, et al. Endocrine, liver-derived IGF-I is of importance for spatial learning and memory in old mice. J Endocrinol. 2006;189(3):617-27.

103. Lupien SB, Bluhm EJ, Ishii DN. Systemic insulin-like growth factor-I administration prevents cognitive impairment in diabetic rats, and brain IGF regulates learning/memory in normal adult rats. J Neurosci Res. 2003;74(4):512-23.

104. Hoshaw BA, Malberg JE, Lucki I. Central administration of IGF-I and BDNF leads to long-lasting antidepressant-like effects. Brain Res. 2005; 1037(1-2):204-8.

105. Castro-Alamancos MA, Torres-Aleman I. Learning of the conditioned eye-blink response is impaired by an antisense insulin-like growth factor I oligonucleotide. Proc Natl Acad Sci USA. 1994:91(21):10203-7.

106. Bluthé R-M, Kelley KW, Dantzer R. Effects of insulin-like growth factor-I on cytokine-induced sickness behavior in mice. Brain Behav Immun. 2006;20(1):57-63

107. Ang LC, Bhaumick B, Juurlink BH. Neurite promoting activity of insulin, insulin-like growth factor I and nerve growth factor on spinal motoneurons is astrocyte dependent. Brain Res Dev Brain Res. 1993;74(1):83-8.

108. Pomerance M, Gavaret JM, Breton M, Pierre M. Effects of growth factors on phosphatidylinositol-3 kinase in astroglial cells. J Neurosci Res. 1995:40(6):737-46.

109. Zawada WM, Kirschman DL, Cohen JJ, Heidenreich KA, Freed CR. Growth factors rescue embryonic dopamine neurons from programmed cell death. Exp Neurol. 1996;140(1):60-7.

110. Masuda S, Chikuma M, Sasaki R. Insulin-like growth factors and insulin stimulate erythropoietin production in primary cultured astrocytes. Brain Res. 1997:746(1-2):63-70.

111. Tranque $P$, Naftolin F, Robbins R. Differential regulation of astrocyte plasminogen activators by insulin-like growth factor-I and epidermal growth factor. Endocrinology. 1994;134(6):2606-13. 
112. Bradshaw SL, Han VK. Hormonal regulation of astroglial insulin-like growth factor (IGF)-binding protein gene expression by IGFs and insulin. Endocrinology. 1993;133(4):1767-77.

113. Aberg ND, Blomstrand F, Aberg MAl, Björklund U, Carlsson B, CarlssonSkwirut $C$, et al. Insulin-like growth factor-l increases astrocyte intercellular gap junctional communication and connexin43 expression in vitro. J Neurosci Res. 2003;74(1):12-22.

114. Suzuki K, Ikegaya Y, Matsuura S, Kanai Y, Endou H, Matsuki N. Transient upregulation of the glial glutamate transporter GLAST in response to fibroblast growth factor, insulin-like growth factor and epidermal growth factor in cultured astrocytes. J Cell Sci. 2001;114(Pt 20):3717-25.

115. Sonnewald U, Wang AY, Petersen SB, Westergaard N, Schousboe A, Erikson $R$, et al. 13C NMR study of IGF-I- and insulin-effects on mitochondrial function in cultured brain cells. NeuroReport. 1995;6(6):878-80.

116. Dringen R, Hamprecht B. Glucose, insulin, and insulin-like growth factor I regulate the glycogen content of astroglia-rich primary cultures. J Neurochem. 1992;58(2):511-7.

117. Masters BA, Werner H, Roberts CT, LeRoith D, Raizada MK. Developmental regulation of insulin-like growth factor-l-stimulated glucose transporter in rat brain astrocytes. Endocrinology. 1991;128(5):2548-57.

118. Spina Purrello V, Cormaci G, Denaro L, Reale S, Costa A, Lalicata C, et al. Effect of growth factors on nuclear and mitochondrial ADP-ribosylation processes during astroglial cell development and aging in culture. Mech Ageing Dev. 2002;123(5):511-20.

119. Matsuda T, Murata Y, Kawamura N, Hayashi M, Tamada K, Takuma K, et al Selective induction of alpha 1 isoform of $(\mathrm{Na}++\mathrm{K}+)$-ATPase by insulin/ insulin-like growth factor-l in cultured rat astrocytes. Arch Biochem Biophys. 1993;307(1):175-82

120. Ridet JL, Malhotra SK, Privat A, Gage FH. Reactive astrocytes: cellular and molecular cues to biological function. Trends Neurosci. 1997;20(12):570-7.

121. Walter HJ, Berry M, Hill DJ, Logan A. Spatial and temporal changes in the insulin-like growth factor (IGF) axis indicate autocrine/paracrine actions of IGF-I within wounds of the rat brain. Endocrinology. 1997;138(7):3024-34.

122. Antoniades HN, Galanopoulos T, Neville-Golden J, Maxwell M. Expression of insulin-like growth factors I and II and their receptor mRNAs in primary human astrocytomas and meningiomas; in vivo studies using in situ hybridization and immunocytochemistry. Int J Cancer. 1992:50(2):215-22.

123. Lara-Diaz VJ, Castilla-Cortazar I, Martín-Estal I, García-Magariño M, Aguirre GA, Puche JE, et al. IGF-1 modulates gene expression of proteins involved in inflammation, cytoskeleton, and liver architecture. J Physiol Biochem. 2017:73:245-58

124. Morales-Garza LA, Puche JE, de la Garza RG, Muñoz-Morón Ú, CastillaCortázar I. Experimental approach to IGF-1 therapy in acute liver damage: acute injury by carbon tetrachloride in controls and mice with partial IGF-1 deficiency. J Hepatol. 2017;66(1):1-14.

125. LeRoith D, Werner H, Beitner-Johnson D, Roberts CT. Molecular and cellular aspects of the insulin-like growth factor I receptor. In: Endocrine reviews, vol. 16. 1995. p. 143-63.

126. Fernandez S, Fernandez AM, Lopez-Lopez C, Torres-Aleman I. Emerging roles of insulin-like growth factor-l in the adult brain. Growth Horm IGF Res. 2007;17(2):89-95.

127. García-Fernández M, Delgado G, Puche JE, González-Barón S, Castilla Cortázar I. Low doses of insulin-like growth factor I improve insulin resistance, lipid metabolism, and oxidative damage in aging rats. Endocrinology. 2008;149(5):2433-42.

128. Castilla-Cortazar I, Guerra L, Puche JE, Munoz U, Barhoum R, Escudero

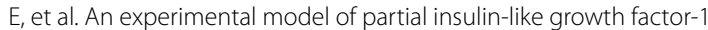
deficiency in mice. J Physiol Biochem. 2013;70:129-39.

129. Puche JE, Muñoz Ú, García-Magariño M, Sádaba MC, Castilla-Cortázar I. Partial IGF-1 deficiency induces brain oxidative damage and edema, which are ameliorated by replacement therapy. Biofactors. 2016:42(1):60-79.

130. Castilla-Cortázar I, Iturrieta I, García-Magariño M, Puche JE, Martín-Estal I, Aguirre GA, et al. Neurotrophic factors and their receptors are altered by the mere partial IGF-1 deficiency. Neuroscience. 2019:404:445-58.

131. Gasperi M, Castellano AE. Growth hormone/insulin-like growth factor I axis in neurodegenerative diseases. J Endocrinol Investig. 2010:33(8):587-91.
132. Gubbi S, Quipildor GF, Barzilai N, Huffman DM, Milman S. 40 years of IGF1: IGF1: the Jekyll and Hyde of the aging brain. J Mol Endocrinol. 2018;61(1):T171-85.

133. Ghazi Sherbaf F, Mohajer B, Ashraf-Ganjouei A, Mojtahed Zadeh M, Javinani A, Sanjari Moghaddam $\mathrm{H}$, et al. Serum insulin-like growth factor-1 in parkinson's disease; study of cerebrospinal fluid biomarkers and white matter microstructure. Front Endocrinol. 2018. https://doi. org/10.3389/fendo.2018.00608/full.

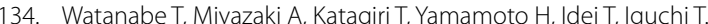
Relationship between serum insulin-like growth factor-1 levels and Alzheimer's disease and vascular dementia. J Am Geriatr Soc. 2005;53(10):1748-53.

135. Laron Z, Pertzelan A, Mannheimer S. Genetic pituitary dwarfism with high serum concentation of growth hormone-a new inborn error of metabolism? Isr J Med Sci. 1966;2(2):152-5

136. Laron Z. Short stature due to genetic defects affecting growth hormone activity. N Engl J Med. 1996;334(7):463-5.

137. Klinger B, Laron Z. Three year IGF-I treatment of children with Laron syndrome. J Pediatr Endocrinol Metab. 1995;8(3):149-58.

138. Castilla-Cortazar I, De Ita JR, Aguirre GA, García-Magariño M, MartínEstal I, Lara-Diaz VJ, et al. Growth hormone insensitivity: Mexican case report. Endocrinol Diabetes Metab Case Rep. 2017. https://doi. org/10.1530/EDM-17-0126.

139. Wu A, Grant DB, Hambley J, Levi AJ. Reduced serum somatomedin activity in patients with chronic liver disease. Clin Sci Mol Med. 1974;47(4):359-66.

140. Picardi A, de Oliveira AC, Muguerza B, Tosar A, Quiroga J, Castilla-Cortázar l, et al. Low doses of insulin-like growth factor-l improve nitrogen retention and food efficiency in rats with early cirrhosis. J Hepatol. 1997;26(1):191-202.

141. Pascual M, Castilla-Cortazar I, Urdaneta E, Quiroga J, Garcia M, Picardi A, et al. Altered intestinal transport of amino acids in cirrhotic rats: the effect of insulin-like growth factor-l. Am J Physiol Gastrointest Liver Physiol. 2000;279(2):G319-24

142. Castilla-Cortázar I, Pascual M, Urdaneta E, Pardo J, Puche JE, Vivas B, et al. Jejunal microvilli atrophy and reduced nutrient transport in rats with advanced liver cirrhosis: improvement by Insulin-like Growth Factor I. BMC Gastroenterol. 2004:4:12

143. Castilla-Cortázar I, Picardi A, Tosar A, Ainzúa J, Urdaneta E, García M, et al. Effect of insulin-like growth factor I on in vivo intestinal absorption of D-galactose in cirrhotic rats. Am J Physiol. 1999;276(1 Pt 1):G37-42.

144. Castilla-Cortazar I, Prieto J, Urdaneta E, Pascual M, Nuñez M, Zudaire E, et al. Impaired intestinal sugar transport in cirrhotic rats: correction by low doses of insulin-like growth factor I. Gastroenterology. 1997;113(4):1180-7.

145. Cemborain A, Castilla-Cortázar I, García M, Quiroga J, Muguerza B, Picardi A, et al. Osteopenia in rats with liver cirrhosis: beneficial effects of IGF-I treatment. J Hepatol. 1998;28(1):122-31.

146. Cemborain A, Castilla-Cortázar I, García M, Muguerza B, Delgado G, Díaz-Sánchez M, et al. Effects of IGF-I treatment on osteopenia in rats with advanced liver cirrhosis. J Physiol Biochem. 2000;56(2):91-9.

147. Castilla-Cortazar I, Quiroga J, Prieto J. Insulin-like growth factor-I, liver function, and hypogonadism in rats with experimentally induced cirrhosis. Hepatology. 2000;31(6):1379.

148. Castilla-Cortazar I, Garcia M, Quiroga J, Diez N, Diez-Caballero F, Calvo $A$, et al. Insulin-like growth factor-I reverts testicular atrophy in rats with advanced cirrhosis. Hepatology. 2000;31(3):592-600.

149. Castilla-Cortázar I, Aliaga-Montilla MA, Salvador J, García M, Delgado G, González-Barón S, Quiroga J, Prieto J. Insulin-like growth factor-I restores the reduced somatostatinergic tone controlling growth hormone secretion in cirrhotic rats. Liver. 2001;21:405-9.

150. Pérez R, García-Fernández M, Díaz-Sánchez M, Puche JE, Delgado G, Conchillo M, et al. Mitochondrial protection by low doses of insulinlike growth factor-l in experimental cirrhosis. World J Gastroenterol. 2008;14:2731-9.

151. García-Fernández M, Castilla-Cortázar I, Díaz-Sanchez M, Navarro I, Puche JE, Castilla A, et al. Antioxidant effects of insulin-like growth factor-I (|GF-I) in rats with advanced liver cirrhosis. BMC Gastroenterol. 2005;5:7.

152. Muguerza B, Castilla-Cortázar I, García M, Quiroga J, Santidrián $\mathrm{S}$, Prieto J. Antifibrogenic effect in vivo of low doses of 
insulin-like growth factor-l in cirrhotic rats. Biochim Biophys Acta. 2001;1536(2-3):185-95.

153. Castilla-Cortazar I, Garcia M, Muguerza B, Quiroga J, Perez R, Santidrian $S$, et al. Hepatoprotective effects of insulin-like growth factor I in rats with carbon tetrachloride-induced cirrhosis. Gastroenterology. 1997;113(5):1682-91.

154. Conchillo M, de Knegt RJ, Payeras M, Quiroga J, Sangro B, Herrero J-I, et al. Insulin-like growth factor I (IGF-I) replacement therapy increases albumin concentration in liver cirrhosis: results of a pilot randomized controlled clinical trial. J Hepatol. 2005;43(4):630-6.

155. Ceda GP, Dall'Aglio E E, Maggio M, Lauretani F, Bandinelli S, Falzoi $\mathrm{C}$, et al. Clinical implications of the reduced activity of the $\mathrm{GH}$ IGF-I axis in older men. J Endocrinol Investig. 2005;28(11 Suppl Proceedings):96-100.

156. Sun LY, Al-Regaiey K, Masternak MM, Wang J, Bartke A. Local expression of GH and IGF-1 in the hippocampus of GH-deficient long-lived mice. Neurobiol Aging. 2005;26(6):929-37.

157. Sonntag WE, Lynch CD, Cooney PT, Hutchins PM. Decreases in cerebral microvasculature with age are associated with the decline in growth hormone and insulin-like growth factor 1. Endocrinology. 1997;138(8):3515-20.

158. Sonntag WE, Carter CS, Ikeno Y, Ekenstedt K, Carlson CS, Loeser RF, et al. Adult-onset growth hormone and insulin-like growth factor deficiency reduces neoplastic disease, modifies age-related pathology, and increases life span. Endocrinology. 2005;146(7):2920-32.

159. Shimokawa I, Higami Y, Tsuchiya T, Otani H, Komatsu T, Chiba T, et al. Life span extension by reduction of the growth hormone-insulinlike growth factor-1 axis: relation to caloric restriction. FASEB J. 2003:17(9):1108-9.

160. Holzenberger M. The GH/IGF-I axis and longevity. Eur J Endocrinol. 2004:151(Suppl):S23-7.

161. Sonntag WE, Bennett C, Ingram R, Donahue A, Ingraham J, Chen H, et al. Growth hormone and IGF-I modulate local cerebral glucose utilization and ATP levels in a model of adult-onset growth hormone deficiency. Am J Physiol Endocrinol Metab. 2006;291(3):E604-10.

162. Maggio M, Lauretani F, Ceda GP, Bandinelli S, Basaria S, Paolisso G, et al. Association of hormonal dysregulation with metabolic syndrome in older women: data from the InCHIANTI study. Am J Physiol Endocrinol Metab. 2007;292(1):E353-8.

163. Groban L, Pailes NA, Bennett CDL, Carter CS, Chappell MC, Kitzman DW, et al. Growth hormone replacement attenuates diastolic dysfunction and cardiac angiotensin II expression in senescent rats. J Gerontol A Biol Sci Med Sci. 2006;61(1):28-35.

164. Li Q, Wu S, Li S-Y, Lopez FL, Du M, Kajstura J, et al. Cardiac-specific overexpression of insulin-like growth factor 1 attenuates aging-associated cardiac diastolic contractile dysfunction and protein damage. Am J Physiol Heart Circ Physiol. 2007;292(3):H1398-403.

165. Puche JE, Castilla-Cortázar I. Human conditions of insulin-like growth factor-I (IGF-I) deficiency. J TransI Med. 2012;10(1):224

166. Tollet-Egnell P, Flores-Morales A, Odeberg J, Lundeberg J, Norstedt G. Differential cloning of growth hormone-regulated hepatic transcripts in the aged rat. Endocrinology. 2000;141(3):910-21.

167. Puche JE, García-Fernández M, Muntané J, Rioja J, González-Barón S, Cortazar IC. Low doses of insulin-like growth factor-l induce mitochondrial protection in aging rats. Endocrinology. 2008;149:2620-7.

168. García-Fernández M, Delgado G, Puche JE, González-Barón S, Cortázar IC. Low doses of insulin-like growth factor I improve insulin resistance, lipid metabolism, and oxidative damage in aging rats. Endocrinology. 2008;149:2433-42.

169. Pellecchia MT, Pivonello R, Salvatore E, Faggiano A, Barone P, De Michele G, et al. Growth hormone response to arginine test distinguishes multiple system atrophy from Parkinson's disease and idiopathic late-onset cerebellar ataxia. Clin Endocrinol. 2005:62(4):428-33.

170. Volpi R, Caffarra P, Scaglioni A, Boni S, Saginario A, Chiodera P, et al. Defective 5-HT 1-receptor-mediated neurotransmission in the control of growth hormone secretion in Parkinson's disease. Neuropsychobiology. 1997;35(2):79-83.

171. Bernhard FP, Heinzel S, Binder G, Weber K, Apel A, Roeben B, et al. Insulin-like growth factor 1 (IGF-1) in Parkinson's disease: potential as trait-, progression- and prediction marker and confounding factors. PLOS ONE. 2016;1 1(3):e0150552.

172. Godau J, Knauel K, Weber K, Brockmann K, Maetzler W, Binder G, et al. Serum insulinlike growth factor 1 as possible marker for risk and early diagnosis of Parkinson disease. Arch Neurol. 2011;68(7):925-31.

173. Godau J, Herfurth M, Kattner B, Gasser T, Berg D. Increased serum insulin-like growth factor 1 in early idiopathic Parkinson's disease. J Neurol Neurosurg Psychiatry. 2010;81(5):536-8.

174. Mashayekhi F, Mirzajani E, Naji M, Azari M. Expression of insulin-like growth factor-1 and insulin-like growth factor binding proteins in the serum and cerebrospinal fluid of patients with Parkinson's disease. J Clin Neurosci. 2010;17(5):623-7.

175. Numao A, Suzuki K, Miyamoto M, Miyamoto T, Hirata K. Clinical correlates of serum insulin-like growth factor-1 in patients with Parkinson's disease, multiple system atrophy and progressive supranuclear palsy. Park Relat Disord. 2014;20(2):212-6.

176. Fiszer U, Michałowska M, Baranowska B, Wolińska-Witort E, Jeske W, Jethon $\mathrm{M}$, et al. Leptin and ghrelin concentrations and weight loss in Parkinson's disease. Acta Neurol Scand. 2010;121(4):230-6.

177. Tuncel D, Inanc Tolun F, Toru I. Serum insulin-like growth factor-1 and nitric oxide levels in Parkinson's disease. Mediators Inflamm. 2009;2009:132464

178. Pellecchia MT, Santangelo G, Picillo M, Pivonello R, Longo K, Pivonello $C$, et al. Insulin-like growth factor-1 predicts cognitive functions at 2-year follow-up in early, drug-naïve Parkinson's disease. Eur J Neurol. 2014;21(5):802-7.

179. Picillo M, Erro R, Santangelo G, Pivonello R, Longo K, Pivonello C, et al. Insulin-like growth factor-1 and progression of motor symptoms in early, drug-naïve Parkinson's disease. J Neurol. 2013:260(7):1724-30.

180. Picillo M, Pivonello R, Santangelo G, Pivonello C, Savastano R, Auriemma $R$, et al. Serum IGF-1 is associated with cognitive functions in early, drug-naive Parkinson's disease. PLOS ONE. 2017:12(10):e0186508

181. Li D-H, He Y-C, Quinn TJ, Liu J. Serum insulin-like growth factor-1 in patients with de novo, drug naïve Parkinson's disease: a meta-analysis. PLOS ONE. 2015:10(12):e0144755.

182. Singleton AB, Farrer M, Johnson J, Singleton A, Hague S, Kachergus $\mathrm{J}$, et al. alpha-Synuclein locus triplication causes Parkinson's disease. Science. 2003;302(5646):841

183. Kumari U, Tan EK. LRRK2 in Parkinson's disease: genetic and clinical studies from patients. FEBS J. 2009;276(22):6455-63.

184. Licker V, Kövari E, Hochstrasser DF, Burkhard PR. Proteomics in human Parkinson's disease research. J Proteomics. 2009;73(1):10-29.

185. Spillantini MG, Schmidt ML, Lee VM, Trojanowski JQ, Jakes R, Goedert M. Alpha-synuclein in Lewy bodies. Nature. 1997;388(6645):839-40.

186. Chung J-Y, Lee S-J, Lee S-H, Jung YS, Ha N-C, Seol W, et al. Direct interaction of a-synuclein and AKT regulates IGF-1 signaling: implication of Parkinson disease. Neurosignals. 2011;19(2):86-96.

187. Kao S-Y. Rescue of a-synuclein cytotoxicity by insulin-like growth factors. Biochem Biophys Res Commun. 2009;385(3):434-8.

188. Kim W, Lee Y, McKenna ND, Yi M, Simunovic F Wang Y et al miR-126 contributes to Parkinson's disease by dysregulating the insulin-like growth factor/phosphoinositide 3-kinase signaling. Neurobiol Aging. 2014;35(7):1712-21.

189. Dulloo AG, Montani J-P. Obesity in Parkinson's disease patients on electrotherapy: collateral damage, adiposity rebound or secular trends? Br J Nutr. 2005:93(4):417-9

190. Chen H, Zhang SM, Schwarzschild MA, Hernán MA, Willett WC, Ascherio A. Obesity and the risk of Parkinson's disease. Am J Epidemiol. 2004:159(6):547-55.

191. Santiago JA, Potashkin JA. Shared dysregulated pathways lead to Parkinson's disease and diabetes. Trends Mol Med. 2013:19(3):176-86.

192. Zaganas I, Kapetanaki S, Mastorodemos V, Kanavouras K, Colosio C, Wilks MF, et al. Linking pesticide exposure and dementia: what is the evidence? Toxicology. 2013;307:3-11.

193. Freire C, Koifman S. Pesticide exposure and Parkinson's disease: epidemiological evidence of association. Neurotoxicology. 2012;33(5):947-71

194. Di Monte DA. The environment and Parkinson's disease: is the nigrostriatal system preferentially targeted by neurotoxins? Lancet Neurol. 2003:2(9):531-8. 
195. Aguirre GA, González-Guerra JL, Espinosa L, Castilla-Cortazar I. Insulin-like growth factor 1 in the cardiovascular system. In: Rev Physiol Biochem Pharmacol. 2018.

196. Zuo L, Motherwell MS. The impact of reactive oxygen species and genetic mitochondrial mutations in Parkinson's disease. Gene. 2013;532(1):18-23.

\section{Publisher's Note}

Springer Nature remains neutral with regard to jurisdictional claims in published maps and institutional affiliations.
Ready to submit your research? Choose BMC and benefit from:

- fast, convenient online submission

- thorough peer review by experienced researchers in your field

- rapid publication on acceptance

- support for research data, including large and complex data types

- gold Open Access which fosters wider collaboration and increased citations

- maximum visibility for your research: over $100 \mathrm{M}$ website views per year

At BMC, research is always in progress.

Learn more biomedcentral.com/submissions 